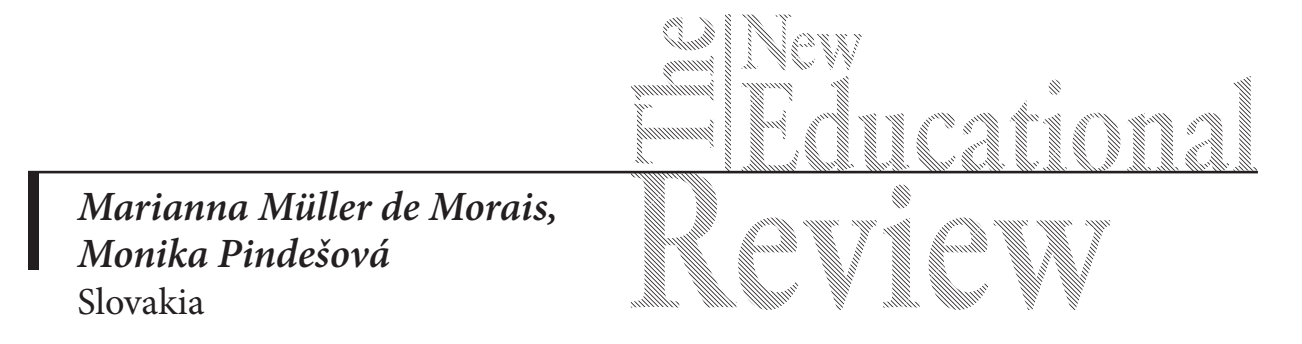

\title{
Perception of the Classroom Climate from the Perspective of Teachers and Pupils
}

DOI: 10.15804/tner.2016.45.3.08

\begin{abstract}
The article deals with the issue of the classroom climate, sets forth its determinants and various approaches to its study. Then it presents selected results of research aimed at finding out differences in classroom climate perception from the perspective of teachers and their pupils at primary school. It also proposes various recommendations for educational practice.
\end{abstract}

Keywords: classroom environment, classroom atmosphere, classroom climate, classroom climate determinants

\section{Introduction}

Classroom climate has an impact on pupils' learning outcomes, behaviour and other personality indicators. It can be stated that at any time there will be room for its scientific study and experimental changes, mostly in order to improve the pedagogical theory, methodology and practice.

Although classroom climate is as old as school or classroom themselves, the term classroom and school climate is relatively new in the terminology. The issue of classroom climate in the conditions of our country has been dealt with by several authors (Grecmanová, 2008; Hanuliaková, 2010; Kosová, 2000; Petlák, 2006; Zelina, 1996, etc.). Abroad, the issue of studying and creating a positive classroom climate has been dealt with, e.g., in the studies by Burden, Fraser (1993), Ekvall 
(1996), Emmer et al. (1994), Fisher, Fraser (1983), Fraser (1986, 1994), Jones (1986), etc.

Many monographs and professional and scientific studies have been published covering the issue, with many papers dealing with classroom and school climate in the general sense. However, there is no exact consensus on how to define the term classroom climate, what parameters to characterize it with, and how to measure the parameters.

We share the opinions of Zelina (1996, p. 155), defining three concepts referring to this issue: classroom (group) setting - expressing ecology of the classroom, its physical and spatial components (e.g., colour, temperature, etc.); classroom (group) atmosphere - expressing social relationships and phenomena of shortterm duration, strong situational dependence, and relatively quickly changeable (e.g., the climate may change several times during one lesson); classroom (group) climate - expressing social relationships in a group, which persist for a longer time, are less changeable, exist regardless of concrete social situations, do not change as quickly as group atmosphere.

Similarly, the term classroom climate can be found in Pedagogický slovník (Pedagogical Dictionary) (Průcha, Walterová, Mareš, 1995, p. 98) as a certain social-pathological variable representing long-term socially and emotionally tuned generalized attitudes and relationships, emotional responses of the pupils of a given classroom to the events in the classroom, including the teacher's educational activities.

Gavora (1999, p. 137) also states that: "classroom climate expresses to what extent the pupil is satisfied in the classroom, whether the pupils understand one another sufficiently, what the extent of competitiveness and rivalry there is among them and what their class cohesiveness is like."

Every classroom has its own specific climate, usually influenced by the pupils' number and gender, mutual trust and cooperation in lessons, relationships built between the teacher and the pupils, nature of tasks and activities, teaching methods, but also by the classroom size, overall climate of the school and other factors. They are divided clearly by Zelina (1996), who includes especially the following three important factors to the key factors creating the classroom climate: the teacher (educator), pupils (children), and activity (tasks).

There are several approaches to the classroom climate study to be found in the domestic and foreign literature. We shall mention some that are mentioned most frequently. They may be approaches: aimed at relationships among teachers, then we speak of the staff climate; aimed at school management and organization, the way of school management and concern for people; aimed at the relation- 
ship dimension - teacher-pupil relationships, relationships among pupils and parent-school relationships; aimed at a more complex approach - school characteristics, composition, parents' satisfaction, information and cooperation with the school (Č́a, Mareš, 2001, pp. 585-589).

There are also other approaches to the classroom climate assessment, such as, e.g., by preference (desirable and actual climate), by the school programme, dynamics, specifics, etc. (Mareš, 2003, p. 40).

\section{Differences in Classroom Climate Perception by Primary School Teachers and Pupils}

\section{Research Methods}

As mentioned above, classroom climate has an impact on the quality of pupils' learning outcomes, their behaviour and other personality indicators. That is why we conducted research (Határová, 2013) with the goal of finding out differences in classroom climate perception from the perspective of primary school teachers and pupils.

The research sample was made up of pupils and class teachers of the $3 \mathrm{rd}$ and $4^{\text {th }}$ forms of town and village elementary schools in the district of Nitra. The respondents were 12 class teachers (women) and 142 pupils ( 80 boys and 62 girls).

In order to fulfil the objectives set, we decided to use the standardized classroom climate diagnostic inventory - MCI (My Class Inventory). The authors of the inventory original version are Fraser and Fisher (1986, as cited in: Mareš, Lašek, 1990). The MCI inventory is for pupils of the $3 \mathrm{rd}$ to $6^{\text {th }}$ forms of elementary school. It enables quick and easy penetration into various areas of classroom life and events. Its evaluation is easy and results offer possibilities for intervention into the classroom social climate.

The inventory consists of 25 questions helping to assess classroom climate in five dimensions: 1 - Satisfaction in the class - the task is to find out pupils' relationship to their class, the extent of satisfaction and enjoyment in class; 2 Friction in the class - finding out the amount of tension, quarrelling, fights in the class, inappropriate social behaviour and general relationship complications; 3 - Competitiveness in the class - finding out efforts of individuals to excel, competitive relationships and how failures are overcome in the class collective; 4 - Difficulty in learning - finding out how pupils perceive educational challenges, 
how they overcome them and the extent to which they find difficulty in learning; 5 - Cohesiveness of the class - finding out friendly and unfriendly relationships among pupils and also the extent of collective cohesiveness.

There are two versions of the MCI inventory: the first one determining the actual classroom climate and the other one determining the preferred classroom climate, pupils' wishes in relation to classroom climate. For our research, we chose the first version - the inventory determining the actual classroom climate.

\section{Research Results and Discussion}

We assumed that there was a statistically significant difference in individual variables of the actual classroom climate between the primary school pupils' perspective and the primary school teachers' perspective, while assuming that the teachers perceived the actual classroom climate more positively.

To test the differences in the value of climate indicators between the teachers and the pupils, first descriptive statistics were calculated for five indicators under study. The descriptive indicators display differences in mean values of the selected indicators and serve as primary indicators of the difference between the groups. The results are presented in Table 1.

Table 1. Descriptive statistics of selected indicators of the classroom climate between the groups of Teachers and Pupils

\begin{tabular}{|c|c|c|c|c|c|c|c|}
\hline & & $\mathrm{N}$ & M & $\begin{array}{l}\text { Me- } \\
\text { dian }\end{array}$ & SD & $\begin{array}{l}\text { Mini- } \\
\text { mum }\end{array}$ & $\begin{array}{l}\text { Maxi- } \\
\text { mum }\end{array}$ \\
\hline \multirow[t]{5}{*}{ Teachers } & Satisfaction & 12 & 11.5 & 11 & 0.9045 & 10 & 13 \\
\hline & Friction & 12 & 7.5833 & 7.5 & 1.6765 & 5 & 10 \\
\hline & Competitiveness & 12 & 11.4167 & 13 & 2.9683 & 5 & 14 \\
\hline & Difficulty & 12 & 9.25 & 9 & 1.0553 & 8 & 12 \\
\hline & Cohesiveness & 12 & 13 & 13 & 1.1282 & 11 & 15 \\
\hline \multirow[t]{5}{*}{ Pupils } & Satisfaction & 142 & 11.4085 & 11 & 1.7429 & 7 & 15 \\
\hline & Friction & 142 & 10.2183 & 10 & 2.7057 & 5 & 15 \\
\hline & Competitiveness & 142 & 11.1479 & 11 & 2.5542 & 5 & 15 \\
\hline & Difficulty & 142 & 10.7535 & 11 & 2.1211 & 5 & 15 \\
\hline & Cohesiveness & 142 & 11.7113 & 12 & 2.1391 & 7 & 15 \\
\hline
\end{tabular}

Legend: $\mathrm{N}$ - number of respondents; $\mathrm{M}$ - mean value; SD - standard deviation 
Based on the values in Table 1, we can see that there are differences in the level of mean values between the groups of teachers and pupils. The greatest differences can be seen in the quantities of Friction (the teachers have a lower mean value) and Cohesiveness (where the teachers have a higher mean value). At the same time, we can see that there is a higher variability of values in the group of pupils (this is indicated by the standard deviation higher values). No considerable difference was found in the other quantities.

To find out the appropriate test to compare the mean levels of the classroom climate indicators, first the character of the data under study was verified. Table 2 displays the test values for the data normal distribution (two tests were used to verify the correctness - the Shapiro-Wilk and the Kolmogorov-Smirnov tests).

Table 2. Normality tests of the classroom climate data

\begin{tabular}{|c|c|c|c|}
\hline & Test & Test value & Test p-value \\
\hline \multirow[t]{2}{*}{ Satisfaction } & Shapiro-Wilk & $0.954305^{\star *}$ & 0.0001 \\
\hline & Kolmogorov-Smirnov & $0.168506^{\star \star}$ & 0.01 \\
\hline \multirow[t]{2}{*}{ Friction } & Shapiro-Wilk & $0.961168^{\star *}$ & 0.0003 \\
\hline & Kolmogorov-Smirnov & $0.118748^{\star *}$ & 0.01 \\
\hline \multirow{2}{*}{$\begin{array}{l}\text { Competitive- } \\
\text { ness }\end{array}$} & Shapiro-Wilk & $0.942213^{\star \star}$ & 0.0001 \\
\hline & Kolmogorov-Smirnov & $0.144277^{\star \star}$ & 0.01 \\
\hline \multirow[t]{2}{*}{ Difficulty } & Shapiro-Wilk & $0.960528^{\star \star}$ & 0.0002 \\
\hline & Kolmogorov-Smirnov & $0.139746^{\star *}$ & 0.01 \\
\hline \multirow[t]{2}{*}{ Cohesiveness } & Shapiro-Wilk & $0.941006^{* *}$ & 0.0001 \\
\hline & Kolmogorov-Smirnov & $0.18139^{\star *}$ & 0.01 \\
\hline
\end{tabular}

Legend: $\mathrm{p}$ - significance; ${ }^{* *}$ - difference between the groups statistically significant at the level of 0.01

Based on the normality test results shown in Table 2, we can state that none of the quantities analysed was of a normal distribution. That was why non-parametric tests were applied to verify the differences between the compared groups. The results of the non-parametric tests are presented in Table 3 (two tests were used to verify the differences - the Kruskal Wallis and the Kolmogorov-Smirnov tests). 
Table 3. Tests of differences in the classroom climate indicators between the teachers and the pupils

\begin{tabular}{llcc}
\hline \multirow{2}{*}{ Satisfaction } & \multicolumn{1}{c}{ Test } & Test value & Test p-value \\
\cline { 2 - 4 } & Kruskal-Wallis & 0.0901 & 0.7641 \\
\cline { 2 - 4 } Friction & Kolmogorov-Smirnov & 0.589538 & 0.8778 \\
\cline { 2 - 4 } & Kruskal-Wallis & $10.6209^{\star *}$ & 0.0011 \\
\hline \multirow{2}{*}{$\begin{array}{l}\text { Competitive- } \\
\text { ness }\end{array}$} & Kolmogorov-Smirnov & $1.639775^{\star *}$ & 0.0092 \\
\cline { 2 - 4 } & Kolmogorov-Smirnov & 0.5512 & 0.4578 \\
\hline Difficulty & Kruskal-Wallis & 7.1922907 & 0.2462 \\
\cline { 2 - 4 } & Kolmogorov-Smirnov & $1.620253^{\star}$ & 0.0073 \\
\hline Cohesiveness & Kruskal-Wallis & $4.7133^{\star}$ & 0.0105 \\
\cline { 2 - 4 } & Kolmogorov-Smirnov & 1.319628 & 0.0614 \\
\hline
\end{tabular}

Legend: $\mathrm{p}$ - significance; ${ }^{*}$ - difference between the groups statistically significant at the level of $0.05 ;^{\star *}$ - difference between the groups statistically significant at the level of 0.01

Based on the results in Table 3 we can see that both tests applied returned a statistically significant difference for the Friction and Difficulty variables. The Cohesiveness variable returned a statistically significant difference only in the Kruskal-Wallis test, allowing us to state that there is a certain difference in the mean values, but not as considerable as in the previous variables. The Satisfaction and Competitiveness variables returned no statistically significant differences between the compared groups (teachers-pupils). The variables that returned statistically significant differences showed that the teachers perceived the classroom climate more favourably than the pupils. That is why teachers should make efforts to create a classroom climate not only for them but in particular for their pupils to feel good, relaxed in their classroom and display joy of staying there.

Similar classroom climate research can be found also in Kurelová and Hanzelková (1996, as cited in: Průcha, J., 2002), where 3 elementary schools with traditional teaching and 3 elementary schools with alternative teaching were compared. It was found out that the alternative schools scored higher than the standard schools in pupils' Satisfaction and Cohesiveness in the class and the standard schools scored higher in pupils' Friction and Competitiveness. There was no difference in Difficulty in learning. Differences between teachers' and pupils' 
opinions were found in the Competitiveness and Cohesiveness variables in the class. Alternative school teachers assessed Competitiveness more positively than pupils. On the other hand, standard school teachers assessed pupils' Competitiveness more negatively than the pupils themselves. When compared with our research, the values found are contradictory.

Another, more extensive study of the classroom climate was conducted by M. Linková (2000, as cited in: Průcha, J., 2002) in Prague primary schools. The author's research did not find any more considerable differences between the pupils of both class types, but for the Friction variable showing higher values in standard classes. Our research returned a similar result, with the Friction variable found in each study of the pupils.

Research similar to ours was carried out also by M. Gottvaldová (2011), studying the difference in classroom climate assessment by primary school pupils and their class teacher in the Czech Republic. The research was carried out in three fourth-form classes. Each class was evaluated separately. The respondents in individual classes were designated as the research sample A, research sample $B$, and research sample C. Research sample "A" showed statistically significant differences in the Satisfaction and Difficulty variables, where the teacher had considerably lower results than the pupils of his class. Similar results in the Difficulty indicator were found also in our research. Thus, it follows from the above that the teachers perceived educational challenges as easier to cope with, unlike the pupils who might find the subject matter difficult. In research sample "B", statistically significant differences were found in the results of classroom climate measurement in the Cohesiveness, Difficulty and Friction variables, where the teacher scored considerably lower than the pupils. Exactly the same variables were found also in our research, with the difference that the teachers had lower mean values in the Friction and Difficulty indicators compared to the pupils. Next, the author found a statistically significant difference between boys and girls in the Competitiveness variable. In research sample "C", statistically significant differences were found in climate perception between the teacher and the pupils in the Friction and Competitiveness variables. In our research, a statistically significant difference was found in terms of gender only in the Friction variable, where the girls assessed the classroom climate as "poorer" with the mean value of $10.8387(\mathrm{p}<0.05)$ and the boys assessed the variable more favourably as "good" by the value of 9.7375 (p < 0.05 ). Based on these results we can state that the girls experienced relationships in the class more sensitively and were affected by arguments among their classmates more emotionally than the boys. The difference in the Satisfaction, Competitiveness and Cohesiveness variables was not confirmed. 
When assessing the results of our research it should be emphasized that it was single, not repeated research. The present research disregards the fact that during the school year classroom climate may change, e.g., because of a change in the teacher or changes due to pupils' ontogenetic development (for more details cf. Průcha, J., 2002). The findings cannot be completely generalized or applied to all primary school pupils.

\section{Conclusions}

Our research found certain differences between the teachers and their pupils in their classroom climate perception. The pupils found school work challenges high, which was proved by the Difficulty indicator. In addition, the pupils and their teachers were of different opinions on the cohesiveness and friendliness in the class, as well as arguments and differences among the pupils, which was indicated by the Cohesiveness and Friction variables. The pupils viewed those indicators more negatively than their teachers. Based on the results, several recommendations were given to the teachers participating in our research, concerning individual dimensions (cf., Doušková, Wágnerová, 1996) where classroom climate is manifested. Some of them are the following:

1) Dimension of mutual relationships: create the atmosphere of security and safety in the classroom; develop pupils' communication skills, encourage mutual communication between the teacher and the pupil as well as among pupils; lead pupils to mutual tolerance, cooperation and help, actively participate in the settlement of conflicts in the class; apply activities aimed at supporting pupils' creativity and productivity, formation of their psycho-social skills (e.g., self-reflection, communication, effective settlement of conflicts, empathy, assertiveness, responsibility, cooperativeness, etc.); provide social-psychological training and developing programmes in school, for pupils or also for their parents, as the case may be, aimed at the development of their emotional and social intelligence, etc.

2) Dimension of individual development: manage lessons so that their entire course motivates pupils; encourage learning out of self-interest, focus on making lessons interesting, educational values, pupils' experiential sphere; effectively apply possibilities for evoking and maintaining pupils' positive motivation (e.g., through the so-called input and ongoing motivation methods, activating methods, methods of differentiated teaching, etc.); enable every pupil to experience success at school; develop self-confidence and teach every pupil to set adequately difficult goals and aspirations for him/herself; show confidence in the pupil's abilities; give 
the pupil enough room to express him/herself and to be listened to; publicize even the smallest success and work results of the pupil, whether in the school or outof-school area; use problem and heuristic learning methods more frequently; in addition to collective forms of teaching at school, use also other group, individual or individualized teaching forms; give pupils room for independent activities and cooperation; pay adequate attention to gifted and talented pupils as well as to poor achievers; make more frequent (shorter in time) walks, as well as thematic, complex or complex inter-subject field trips and an excursion at the end of the school year, with a well-thought-out preparation, organization and use, etc.

3) Dimension of the system: contribute to increasing the involvement of pupils in school matters and their internal motivation; strengthen activities and projects of the class; enable pupils to found and publish a school magazine, to which they could make contributions according to their interests in nature, culture, art, sports or social life; more frequently apply forms of positive appraisal of the pupil that reinforce the pupil's desirable behaviour more effectively than a negative assessment, criticism, moralizing, punishment, intimidation or ignoring the pupil; acknowledge every, even the smallest progress; actively participate in the settlement of conflicts in the class; in cooperation with other experts carry out regular talks, discussions and debates in groups of pupils, dealing not only with problems in behaviour or learning, but also other difficulties and problems worrying them; strengthen cooperation between family and school not only when there are educational problems with pupils, but mainly to create optimal conditions for maximum possible development of pupils with regard not only to their cognitive, but also social-emotional development; provide help to pupils and their parents in crisis situations by means of professional (psychological, educational, social) counselling, etc.

\section{References}

Burden, R., \& Fraser, B.J. (1993). Use of classroom environment assessments in schol psychology: A British perspective. In Psychology in the Schools, 30(3), 232-240.

Čapek, R. (2010). Trí́dni klima a školní klima. Praha, 328 p.

Č́́p, J., \& Mareš, J. (2001). Psychologie pro učitele. Praha: 655 p.

Doušková, A., \& Wágnerová, O. (1996). Niekolko poznámok k ekologickej výchove

z pohladu pedagogickej zložky prípravy učitelov. In Environmentálna výchova a škola: zborník z konferencie. Banská Bystrica, 29-35.

Ekvall, G. (1996). Organizational Climate for Creativity and Innovation In European Journal of Work and Organizational Psychology, 5(1), 105-123. 
Emmer, E.T. et al. (1994). Classroom management for secondary teachers (3rd ed.). NeedhamHeights, MA: Allyn and Bacon. 236 p.

Fisher, D.L., Fraser, B.J. (1983). Validity and use of Classroom Environment Scale. In Educational Evaluation and Policy Analysis, 5(3), 261-271.

Fraser, B.J. (1986). Classroom environment. London: Croom Helm. 226 p.

Fraser, B.J. (1994). Research on classroom and schoolclimate. In Gabel, D. (Ed.).

Handbook of research on science teaching and learning. New York: Macmillan, 493-541.

Gavora, P. (2010). Akí sú moji žiaci? Nitra: 216 p.

Gottvaldová, M. (2011). Rozdílnost v posuzování klimatu třídy žáky a třídním učitelem na prvním stupni základní školy. Diploma work. Brno: MU, 92 p.

Grecmanová, H. (1998). Pojetí školní klimatu ve vedecké literatuře. In Pedagogická orientace, $4(1), 27-35$.

Hanuliaková, J. (2010). Kreovanie klímy triedy v edukačnej praxi. Bratislava, 102 p.

Határová, M. (2013). Rozdiely vo vnímaní klímy triedy z pohladu učitela a žiakov. Diploma work. Nitra: PF UKF, 80 p.

Jones, V., \& Jones, L.S. (1986). Comprehensive classroom management: Creating positive learning environments. Boston: Allyn and Bacon. 459 p.

Kosová, B. (2000). Rozvoj osobnosti žiaka. Prešov, 121 p.

Mareš, J., \& Lašek, J. (1990). Známe sociální klima ve výuce? In Výchova a vzdělávání, 1(8) $173-176$.

Mareš, J. (1998). Sociální klima školní třídy. online. 1998. Available on the Internet: http:// www.klima.pedagogika.cz/trida/doc/Mares_Klima_tridy.pdf

Petlák, E. (2006). Klíma školy a klíma triedy. Bratislava, 119 p.

Průcha, J., \& Walterová, E., \& Mareš, J. (1995). Pedagogický slovník. Praha, 292 p.

Průcha, J. (2002). Moderní pedagogika. Praha: 481 p.

Seebauerová, R. (2005). Školská a triedna klíma: Rakúsky pohlad. In Pedagogická revue, 57(4), 348-361.

Zelina, M. (1996). Stratégie a metódy rozvoja osobnosti dietata. Bratislava, 228 p. 